\author{
Seed를 이용한 단결정 초내열합금 CMSX-4에서 \\ 응고속도 및 열처리에 따른 미세조직 변화 \\ 권순철 $^{1} \cdot$ 신종호 ${ }^{2} \cdot$ 임근영 ${ }^{1} \cdot$ 성기태 ${ }^{1} \cdot$ 윤병관 $^{3} \cdot$ 정의석 ${ }^{3} \cdot$ 이재현 ${ }^{1, *}$ \\ 1창원대학교 신소재공학부 \\ 2두산중공업(주) 기술연구소 \\ 3한국로스트왁스(주) 기술연구소
}

\title{
Microstructural Evolution with Solidification Rate and Heat-Treatment of Single Crystal Superalloy CMSX-4 Grown using Seed
}

\author{
Suncheol Kwon', Jongho Shin², Geunyoung Rim¹, Gitae Sung', \\ Byunggwan Yoon $^{3}$, Euisuk $\mathrm{Jung}^{3}$, and Jehyun Lee ${ }^{1, *}$ \\ ${ }^{1}$ Department of Materials Science and Engineering, Changwon National University, Changwon 51140, Republic of Korea \\ ${ }^{2}$ R\&D Center, Doosan Heavy Industries \& Construction Co. Ltd, Changwon 51711, Republic of Korea \\ ${ }^{3} R \& D$ Center, Korea Lost Wax Co. Ltd, Ansan 15407, Republic of Korea
}

\begin{abstract}
The CMSX-4 superalloy including refractory elements was directionally solidified using the seed of a [001] single crystal to control the growth direction to [001], where solidification velocity was changed from 25 to $160 \mu \mathrm{m} / \mathrm{s}$. In the log-log plot between spacing and solidification velocity, the primary dendrite arm spacing and secondary dendrite arm spacing linearly decreased with slopes of -0.288 and -0.318 , respectively, as solidification velocity increased. A $\gamma / \gamma^{\prime}$ eutectic structure was observed in the interdendritic region and the size linearly decreased with increasing solidification velocity. However, the volume fraction of the $\gamma / \gamma^{\prime}$ eutectic structure did not change significantly with solidification velocity. Micro-segregation of the refractory elements was found in the primary dendrite arm region. These elements were not uniformly distributed even after solid-solution heat treatment, and an irregularly coarse $\gamma^{\prime}$-phase was observed in the interdendritic region after heat-treatment.
\end{abstract}

(Received July 11, 2018; Accepted August 16, 2018)

Keywords: superalloy, directional solidification, seed, single crystal

\section{1. 서 론}

$\mathrm{Ni}$ 기 단결정 초내열합금 $\mathrm{CMSX}-4$ 는 고온에서 사용되는 발전 및 항공용 가스터빈 엔진의 터빈 블레이드에 널리 사 용되고 있다. 터빈 블레이드는 고속으로 회전하면서 고온 에서 지속적으로 노출되기 때문에 우수한 크리프 강도와 고온산화 특성이 요구되는 터빈엔진의 주요 부품이다. 가 스터빈의 효율향상을 위해서 가스터빈 입구 온도(Turbine Inlet Temperature, TIT)가 높아지고 있어, 높은 응력과 고 온에 노출되는 터빈 블레이드의 온도 수용성을 향상시키기 위해 합금설계, 주조공정, 냉각공 설계, 단열코팅 공정 등

*Corresponding Author: Jehyun Lee [Tel: +82-55-213-3695, E-mail: ljh@changwon.ac.kr] Copyright (C) The Korean Institute of Metals and Materials
터빈 블레이드 설계 및 공정 연구 개발이 지속적으로 진행 되고 있다. 특히 터빈 블레이드의 고온특성을 향상 시키기 위해 진공 정밀주조 방법이 적용되며 결정립을 다결정에서 일방향 및 단결정으로 제어되고 있다.

본 연구에 사용된 CMSX-4 합금은 단결정 초내열 합금 으로서 $\mathrm{W}, \mathrm{Ta}$, 그리고 $\mathrm{Mo}$ 와 같은 고용강화 원소들을 다 량 첨가하여 고온에서 크리프 강도와 미세조직의 안정성을 향상시킨 합금이다. 특히 터빈 블레이드의 가용온도를 증 가시키는 $\mathrm{Re}$ 이 $3 \mathrm{wt} \%$ 첨가되어 제 2세대 단결정 초내열 합금으로 분류되고 있다 $[1,2]$. 그러나 $\mathrm{Re}$ 이 과잉 첨가된 합금에서는 고온 환경에서 장시간 노출되었을 때 기계적 특성을 저하시키는 TCP(Topologically close-packed) 상 (Phase) 형성을 초래하여 이를 개선하기 위해 $\mathrm{Ru}$ 원소를 첨가한 4,5 세대 초내열합금이 개발되었다 [3-5]. 
Table 1. Chemical composition of CMSX-4 (unit: wt\%).

\begin{tabular}{ccccccccccc}
\hline Composition & Co & Cr & Mo & W & Al & Ti & Ta & Hf & Re & Ni \\
\hline wt $\%$ & 9.0 & 6.5 & 0.6 & 6.0 & 5.6 & 1.0 & 6.5 & 0.1 & 3.0 & Bal. \\
\hline
\end{tabular}

다양한 합금 원소들이 용해되었을 때, 액상에서 균일 하게 분포하지만 응고 중에는 용질 원소들은 평형분배계 수 $(k)$ 에 따라서 재분배되며 이는 다음 식으로 표현할 수 있다.

$$
k=\mathrm{C}_{\mathrm{S}} / \mathrm{C}_{\mathrm{L}}
$$

여기서 $\mathrm{C}_{\mathrm{S}}$ 와 $\mathrm{C}_{\mathrm{L}}$ 은 평형상태도에서 일정 온도의 액상선 조 성과 고상선 조성이다. $k$ 값이 1 보다 적으면 결정이 성장하 면서 용질 원소는 액상으로 배출되고, $k$ 값이 1 보다 크면 용질 원소는 액상보다 높은 고용도를 가지게 된다. 용질원 소의 분포가 중요한 이유는 편석으로 인해 $\gamma^{\prime}$ 상의 형상과 크기가 불균일하게 되어 고온 환경에서 사용 중 기계적 특 성에 악영향을 미치기 때문이다 [6-9]. 응고 중 용질 원소 의 분포에 대하여 체계적으로 연구하기 위해 일정한 방위 로 결정을 성장시킬 수 있는 방법이 필요하여 단결정 시드 를 사용하였다 [10-12]. CMSX-4 초내열합금은 단결정 터 빈 블레이드 합금으로 널리 사용되고 있으나, 응고 속도가 용질원소의 재분배에 의한 공정상의 형상 변화에 미치는 영향, 열처리 후 용질원소의 재분포와 $\gamma^{\prime}$ 상의 형상과 크기 의 상관 관계 등 단결정 합금의 공정상 형성과 편석에 대 한 연구가 진행되고 있다.

본 연구에서는 $\mathrm{Ni}$ 기 초내열 합금 $\mathrm{CMSX}-4$ 합금에 [001] 방위의 단결정 시드를 사용하여 일정한 온도 경사 조건에서 다양한 응고 속도로 단결정을 성장시켜 응고 거 동 및 미시편석에 대한 연구하였으며, $50 \mu \mathrm{m} / \mathrm{s}$ 와 $160 \mu \mathrm{m} /$ $\mathrm{s}$ 의 응고 속도에서 성장시킨 단결정을 열처리 후 용질원소 의 재분포와 미세조직 변화에 대하여 연구하였다.

\section{2. 실험방법}

본 연구에 사용된 $\mathrm{Ni}$ 기 단결정 초내열 합금 $\mathrm{CMSX}-4$ 의 조성을 표 1에 나타내었다.

일방향 응고 장비는 가열로와 절연부, 양의 온도구배를 형성시키는 냉각부로 구성된 개량형 Bridgman 방식의 일 방향 응고 장치를 이용하였다 $[13,14]$. 잉곳을 제작한 후, 직경 $4.7 \times$ 길이 $140 \mathrm{~mm}^{2}$ 의 봉상 시편을 방전 가공을 통 해 채취하였다. 방전 가공 중에 형성된 산화 피막을 제거한 후에 알루미나 튜브(OD: $8 \mathrm{~mm}, \mathrm{ID}: 5 \mathrm{~mm}, \mathrm{~L}: 700 \mathrm{~mm})$ 에 시편을 장입 후 일방향 응고 장비에 고정하였다.
알루미나 튜브 내부는 불활성 $\mathrm{Ar}$ 가스 분위기로 조성한 후 용탕 온도를 $1600{ }^{\circ} \mathrm{C}$ 로 유지하여 봉상 시편과 시드의 상부 약 $3 \mathrm{~mm}$ 를 용해시켰다. 고상/액상 계면의 안정화를 위하여 30 분간 유지 후 로를 위쪽 방향으로 다양한 응고 속도로 $50 \mathrm{~mm}$ 를 성장시켰다. 응고 진행 중에 고상/액상 계면 형상을 관찰하기 위하여 물에 급냉하였다. 이 때 온 도 구배 $(\mathrm{G})$ 는 $17.3 \mathrm{~K} / \mathrm{mm}$ 로 일정하게 유지하면서 응고 속 도(V)는 $25,50,100$, 그리고 $160 \mu \mathrm{m} / \mathrm{s}$ 로 일정한 속도로 일방향 응고되었다. 각 응고 속도에서 응고된 시편을 길이 방향과 수직 방향으로 절단 및 연마한 후 Kalling’s $2(3 \mathrm{~g}$ $\mathrm{CuCl}_{2}, 30 \mathrm{~mL} \mathrm{HCl}, 70 \mathrm{~mL}$ Ethanol) 용액으로 부식시켜 광학현미경을 이용하여 미세조직을 관찰하였다. 응고 속도 별 1차 수지상 간격(Primary dendrite arm spacing, PDAS) 및 2차 수지상 간격(Secondary dendrite arm spacing, $\mathrm{SDAS}$ )을 화상분석 프로그램을 이용하여 측정하 였다. 상 (Phase) 분석 및 성장한 수지상의 방위 측정을 위해 주사전자현미경(Scanning electron microscopy, $\mathrm{SEM}$ ) 및 전계 방사형 주사전자현미경(Field emission scanning electron microscope, FE-SEM)을 사용하였으며, 편석 정도를 관찰하기 위해 급냉된 시편의 고상/액상 계면 으로부터 $20 \mathrm{~mm}$ 아래 위치에서 성장방향으로부터 수직으 로 절단하여 전자 탐침 미량분석기(Electron Probe MicroAnalyzer, EPMA)를 이용하여 관찰하였다.

가열 및 냉각 과정에서 발생하는 상변태 온도를 측정하 기 위해 시차주사열량 측정법(Differential Scanning Calorimetry, $\mathrm{DSC}$ )으로 열분석 시험을 실시하였으며, 이 때 승온 및 냉각 속도는 $10 \mathrm{~K} / \mathrm{min}$ 으로 수행하였다.

\section{3. 결과 및 고찰}

\subsection{DSC 열분석}

본 연구에서 사용된 단결정 초내열합금 $\mathrm{CMSX}-4$ 의 일방 향 응고 과정에서 발생하는 상변태의 온도를 확인하기 위 해 DSC 열분석을 실시하여 냉각 곡선과 승온 곡선의 결 과를 그림 1에 나타내었다. 냉각 곡선(그림 1(a))에서 초정 $\gamma$ 상이 $1371{ }^{\circ} \mathrm{C}$ 에서 형성되기 시작하고 $\gamma^{\prime}$ 상이 $1310{ }^{\circ} \mathrm{C}$ 에 서 형성되어 $1277^{\circ} \mathrm{C}$ 에서 $\gamma / \gamma^{\prime}$ 반응으로 인해 응고가 완료 되는 것이 측정되었고 $\gamma$ 상 내에 $\gamma^{\prime}$ 상이 $1218^{\circ} \mathrm{C}$ 에서 석출 되는 것을 확인할 수 있었으며 그 이외의 다른 반응은 관 


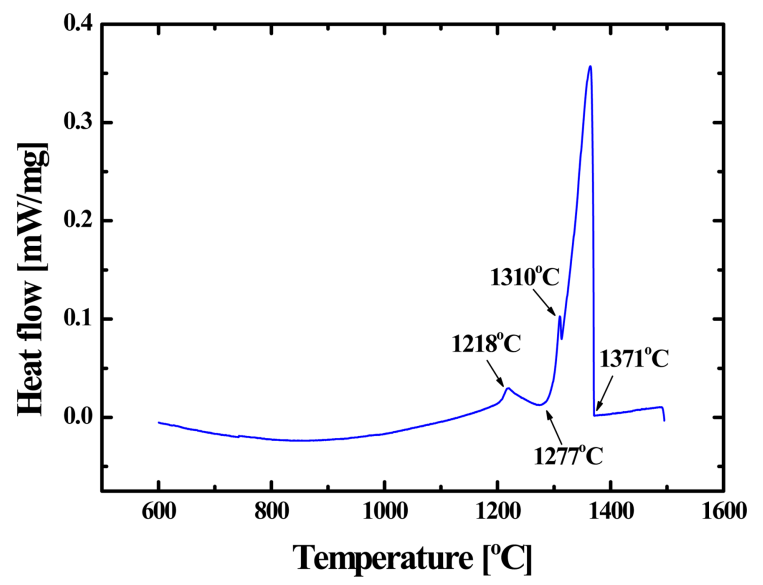

(a)

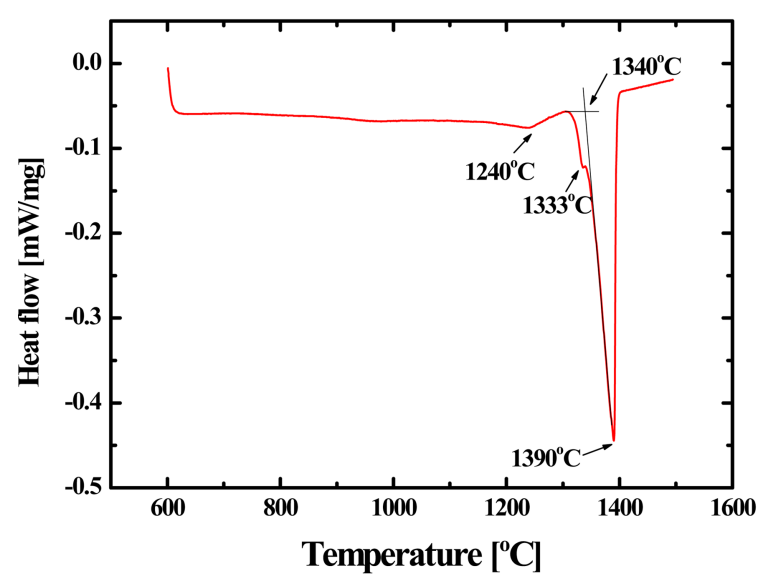

(b)

Fig. 1. DSC curves under heating and cooling rate of $10 \mathrm{~K} / \mathrm{min}$ : (a) the cooling curve and (b) heating curve.
찰되지 않았다. 여기서, 고상/액상 공존 구간(Mushy zone) 은 $94{ }^{\circ} \mathrm{C}$ 인 것을 확인할 수 있었다. 가열 곡선(그림 1(b)) 을 통해 액상선 온도 $\left(\mathrm{T}_{\mathrm{L}}\right)$ 는 $1390{ }^{\circ} \mathrm{C}$, 고상선 온도 $\left(\mathrm{T}_{\mathrm{S}}\right)$ 는 $1340{ }^{\circ} \mathrm{C}$ 로 나타났다.

\subsection{Seed를 이용한 단결정 성장 거동}

그림 2는 합금의 단결정 성장을 위해 알루미나 튜브 내 [001] 방향의 시드와 잉고트를 장입한 후 $50 \mu \mathrm{m} / \mathrm{s}$ 의 응고 속도로 일방향 응고한 시편에 대한 길이방향의 광학사진을 보여준다. 그림 2(a)에서 가열로의 위치를 조정하여 시드의 팁으로부터 $3 \mathrm{~mm}$ 와 잉고트를 용해시킨 후 일방향 응고한 시편이 수지상으로 성장하였음을 관찰할 수 있었다. $\mathrm{Cu}$ 냉 각부에 위치하고 있는 시드(그림 2(b))는 용융되지 않았지 만 고상/액상 계면에 근접할수록 열의 영향으로 균질화 효 과에 따른 수지상과 수지상 사이에서 용질의 확산에 의해 서 수지상 미세구조의 선명도가 낮아진 것을 확인할 수 있 었다(그림 2(c)). 그림 2(d)에서 초기 안정화된 계면을 확 인할 수 있으며, 응고속도 $50 \mu \mathrm{m} / \mathrm{s}$ 로 성장시켰을 때 조성 적 과냉(constitutional undercooling)에 의해서 계면이 불 안정하게 되어 많은 수의 1 차 수지상이 성장하였지만 경 쟁 성장을 통해 일정 간격의 1 차 수지상만이 성장하게 되 었다. 알루미나 튜브 내에 장입된 [001] 방위의 시드로부 터 성장하기 때문에 성장하는 수지상의 방위는 [001] 방위 와 동일한 방위로 성장하게 된다(그림 2(e)).

본 실험에 사용된 시드와 일방향 응고한 시편의 수지상 방위를 그림 3에 나타내었다. 시드의 경우 [001] 방향으로 부터 $4.7479^{\circ}$ 의 방위를 가지는 것으로 관찰되었으며, 새롭
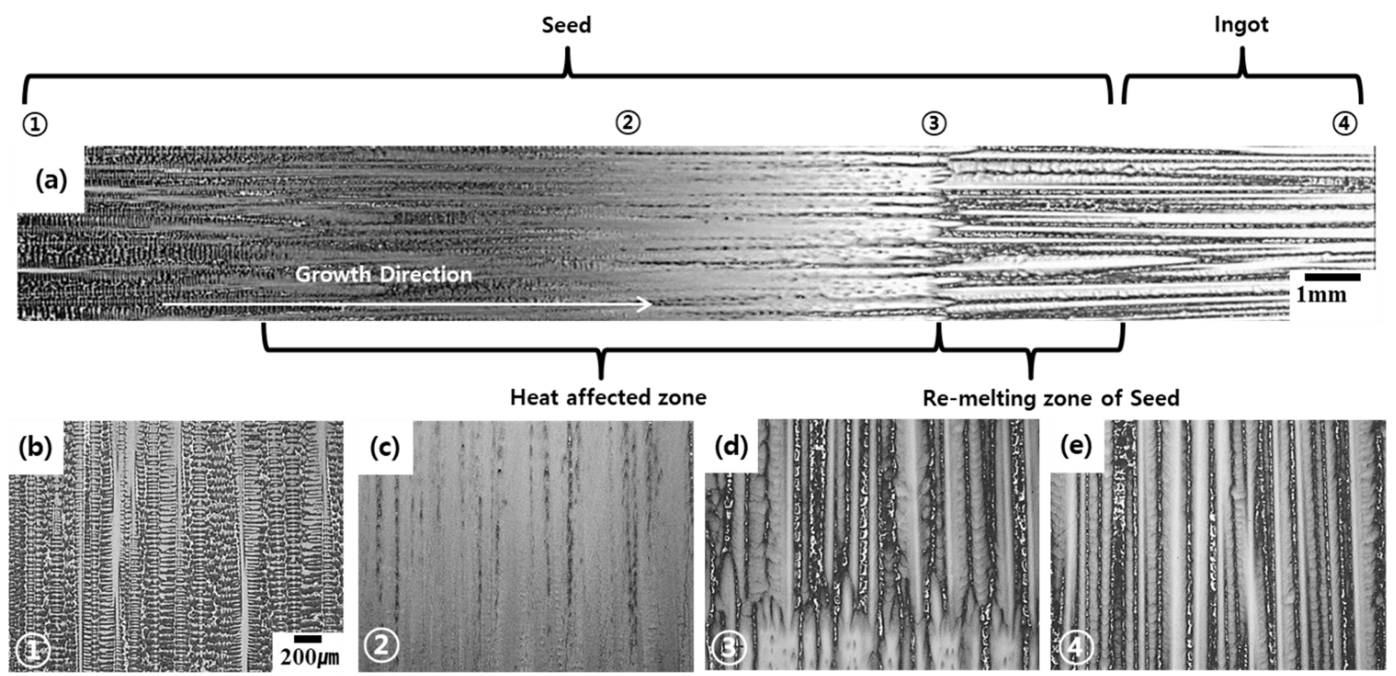

Fig. 2. Microstructure variation with distance after directional solidification using seed: (a) full view of the initial stage of solidification, microstructures at (b) bottom part of seed, (c) just below the initial S/L interface, (d) at the initial S/L interface, and (e) at initial stage of solidification velocity of $50 \mu \mathrm{m} / \mathrm{s}$. 


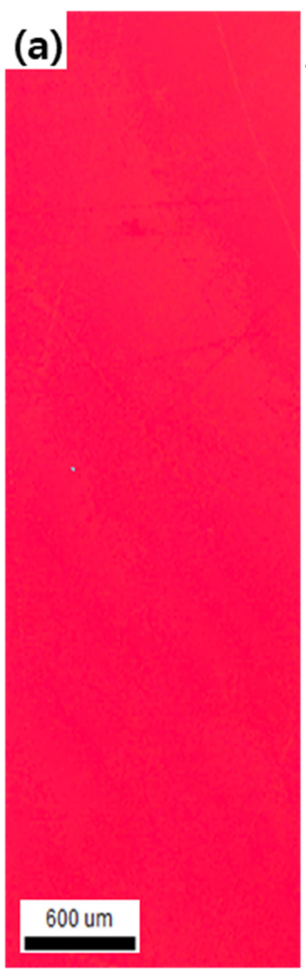

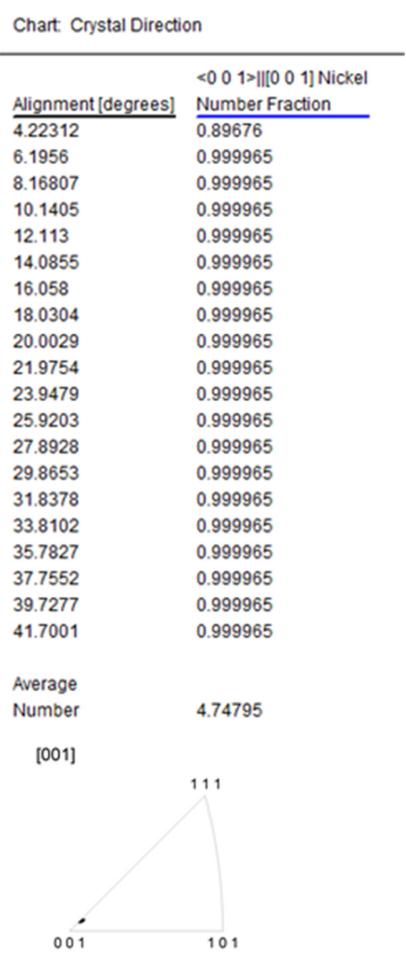

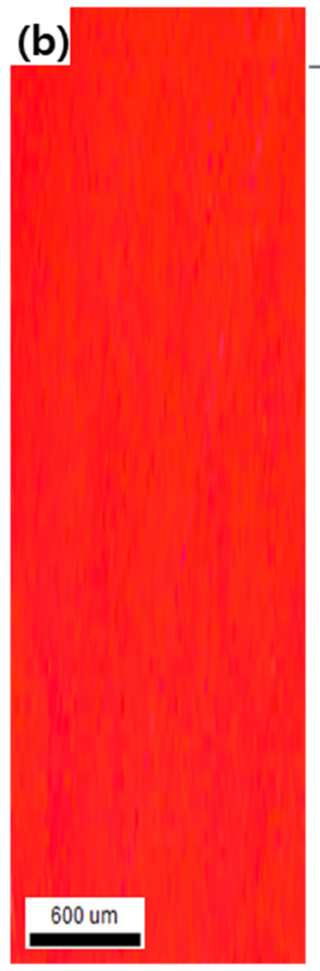

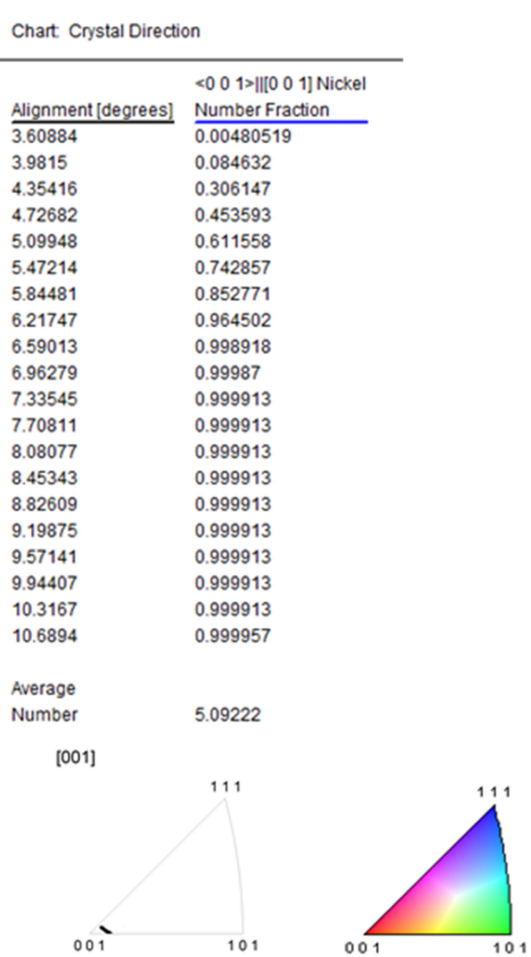

Fig. 3. Tilting angle from [001] direction in the specimen cross-sectioned at (a) the seed and (b) the crystal grown at $50 \mu \mathrm{m} / \mathrm{s}$.

게 성장한 수지상의 경우 $5.0922^{\circ}$ 의 방위로 성장하는 것을 확인할 수 있었다. 이 두 수지상의 방위가 차이가 발생하 는 이유는 시드를 알루미나 튜브 내 장입하기 전 산화층을 제거 후 알루미나 튜브와 시드 사이의 갭에 의해 시드가 기울어 질 수 있는 것으로 판단되며, 결과적으로 시드의 방위가 새롭게 성장하는 수지상의 방위에 절대적으로 영향 을 미치는 것을 알 수 있다.

그림 2(d)에 나타난 것처럼 응고 초기 조성적 과냉에 의 해서 경쟁 성장이 발생하는데, 안정화된 초기 고상/액상 계 면의 직상과 직하 $5 \mathrm{~mm}$ 구간에서 수직으로 절단하여 미세 조직을 관찰하여 그림 4에 나타내었다. 본 연구의 경우 실 험 과정에서 알루미나 튜브 내에 시드를 장입한 후 실험을 진행하기 때문에 알루미나 튜브와 시드 사이에서 약간의 공간이 발생한다. 금속을 용융시키는 과정에서 중력에 의 해 아래 방향으로 용탕이 흘러내리게 되고 냉각수 부분에 의해서 다시 응고하여 불균일 핵생성을 이루는 것을 확인 할 수 있다(그림 4(a)). 불균일하게 생성된 핵들도 수지상 으로 성장할 수 있는 시드가 될 수 있으며, 단결정 시드와 경쟁하여 성장하게 된다. 본 실험의 경우 그림 4(b)에 나 타낸 것처럼 단결정이 성장되었으며, 성장 방향은 단결정 시드와 동일한 방향임을 확인할 수 있었다 [15].
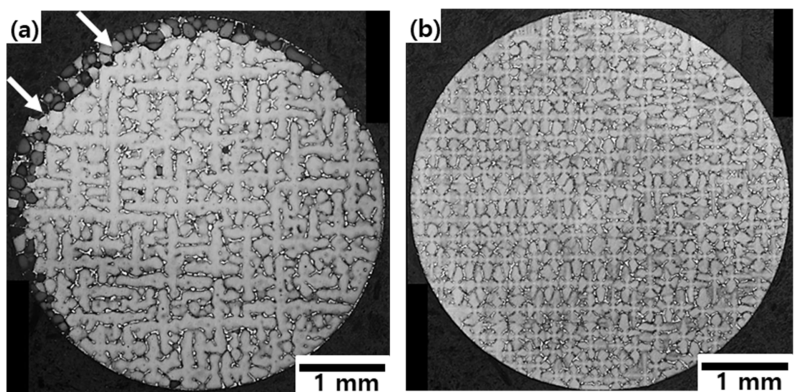

Fig. 4. Cross-sectional microstructure variation at (a) initial stage and (b) steady state at solidification velocity of $50 \mu \mathrm{m} / \mathrm{s}$.

\section{2 응고속도에 따른 수지상 형상 변화}

[001] 방위의 시드를 이용하여 다양한 응고 속도로 일방 향 응고를 수행하였으며, 고상/액상 계면의 형상 변화를 관 찰하기 위하여 성장 중에 수냉하여 그림 5에 나타내었다. 모든 응고 속도에서 2 차 수지상이 잘 발달된 수지상으로 성장하며 수지상 방위는 일정하게 성장하는 것을 확인할 수 있었다. 동일한 [001] 시드를 사용하더라도 응고 속도 증가에 따라 효과적으로 용질 원소를 액상으로 배출하기 위해 1 차 및 2 차 수지상 간격이 미세하게 변하는 것을 알 수 있다.

그림 6은 고상/액상 계면으로부터 $20 \mathrm{~mm}$ 직하에서 수직 

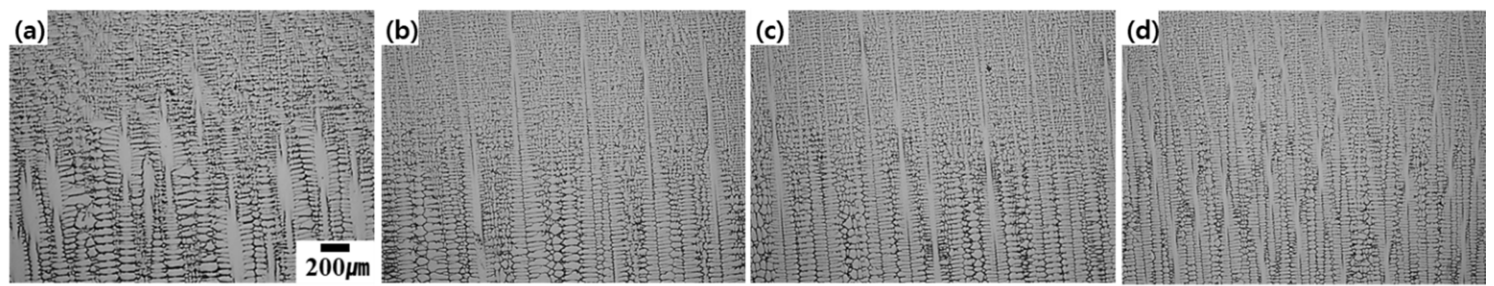

Fig. 5. Variation of interface morphology with increasing growth velocity: (a) 25 , (b) 50 , (c) 100 , and (d) $160 \mu \mathrm{m} / \mathrm{s}$.
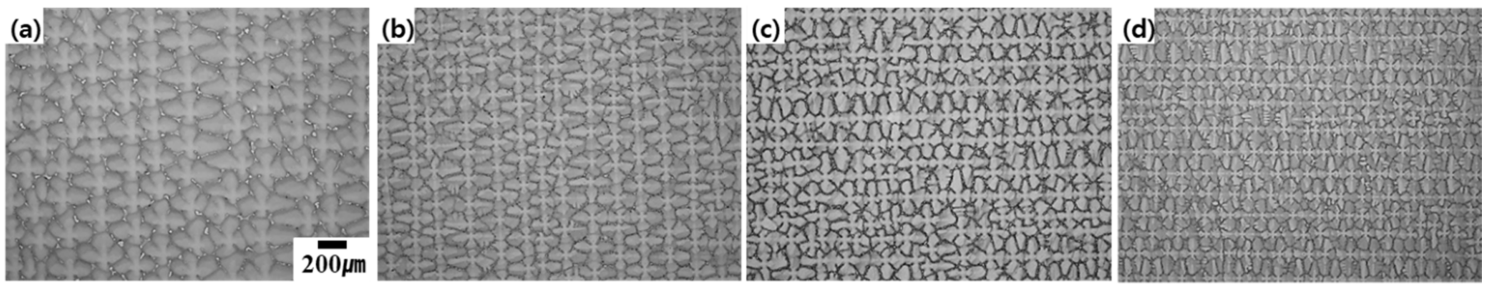

Fig. 6. Variation of the cross-sectional morphology below $20 \mathrm{~mm}$ of the solid/liquid interface with increasing growth velocity: (a) 25 , (b) 50 , (c) 100 , and (d) $160 \mu \mathrm{m} / \mathrm{s}$.
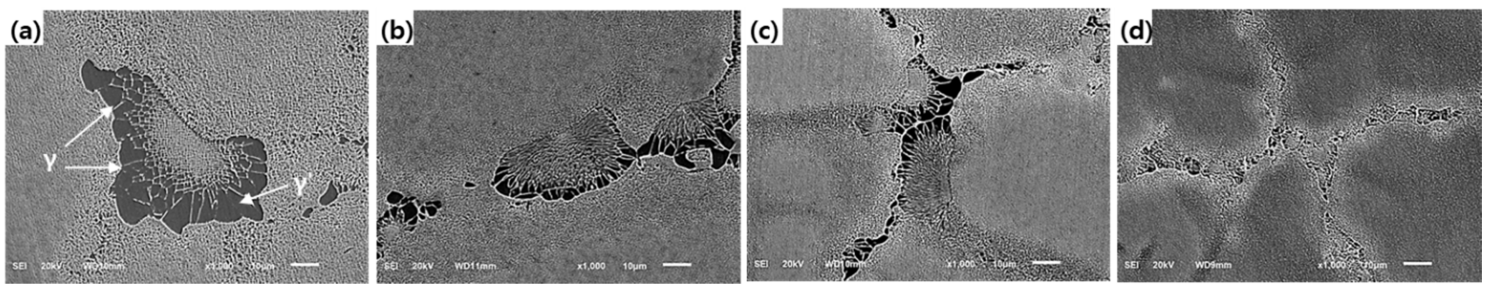

Fig. 7. Morphology variation of $\gamma / \gamma^{\prime}$ Eutectic structure with growth velocity: (a) 25, (b) 50, (c) 100, and (d) $160 \mu \mathrm{m} / \mathrm{s}$.

으로 절단하여 관찰한 미세조직이다. 2차 수지상이 잘 발 달하였으며 응고 속도가 증가할수록 수지상 간격이 감소하 는 것을 관찰할 수 있었다. 수지상으로 응고가 진행될 때 고용 한도(solubility limit) 이상의 용질 원소를 배출함에 따라 수지상 사이에서는 최종 응고 조직인 $\gamma / \gamma^{\prime}$ 공정상이 형성된다. 여기서 수지상 간격이 미세할수록 용질원소의 미 세 편석의 정도는 감소하면서 균일하게 되어 $\gamma / \gamma^{\prime}$ 공정상 의 크기에 영향을 미칠 수 있다.

응고 속도에 따른 수지상 사이에 형성된 공정조직 변화

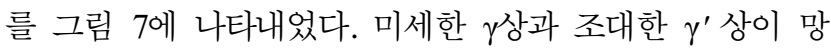
상으로 이루어져 있는 $\gamma / \gamma^{\prime}$ 공정상이 수지상 사이에서 관 찰되었다. 응고 속도가 증가할수록 $\gamma / \gamma^{\prime}$ 공정상의 크기는 작아 지면서 공정상 내에 조대한 $\gamma^{\prime}$ 의 크기가 현저하게 작아지는 것이 관찰되었다. $\gamma / \gamma^{\prime}$ 공정상의 평균 두께와 면 적 분율을 그림 8에 나타내었다. $\gamma / \gamma^{\prime}$ 공정상의 평균 두께 는 응고속도가 증가할수록 선형적으로 감소하는 것을 알 수 있으며, 면적 분율은 합금 조성에 의존하기 때문에 응 고속도의 증가에 따라서 거의 변화 없이 약 $8-10 \%$ 정도로 균일하였다. 이 결과에서 응고속도 증가에 따른 $\gamma / \gamma^{\prime}$ 공정

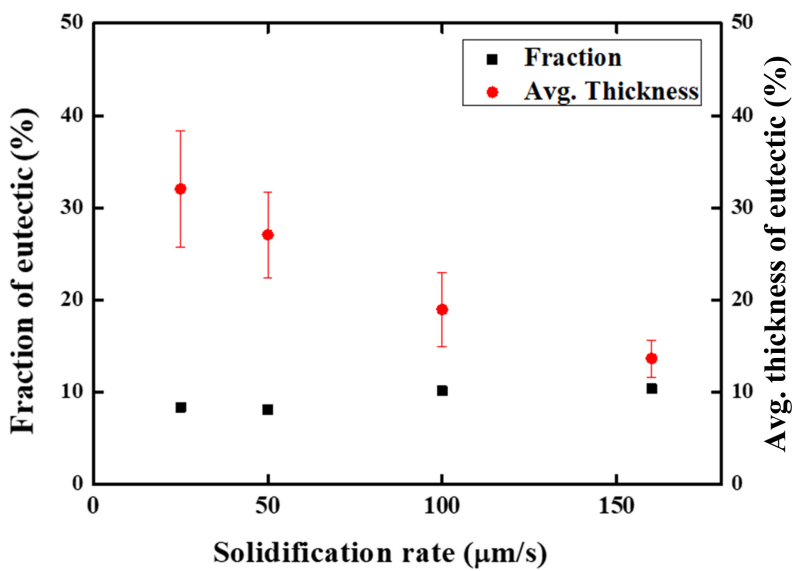

Fig. 8. Variation of the average thickness and the area fraction of $\gamma /$ $\gamma^{\prime}$ eutectic structure.

상의 분율은 거의 일정하지만 미세한 $\gamma / \gamma^{\prime}$ 공정상이 균일 하게 분포하며 $\gamma / \gamma^{\prime}$ 공정상 내의 $\gamma^{\prime}$ 상의 크기가 작아지는 것을 확인할 수 있었다.

일방향 응고시 수지상 간격은 온도 구배와 응고속도에 의존하게 된다. 고상/액상 계면이 수지상으로 성장할 때 1 


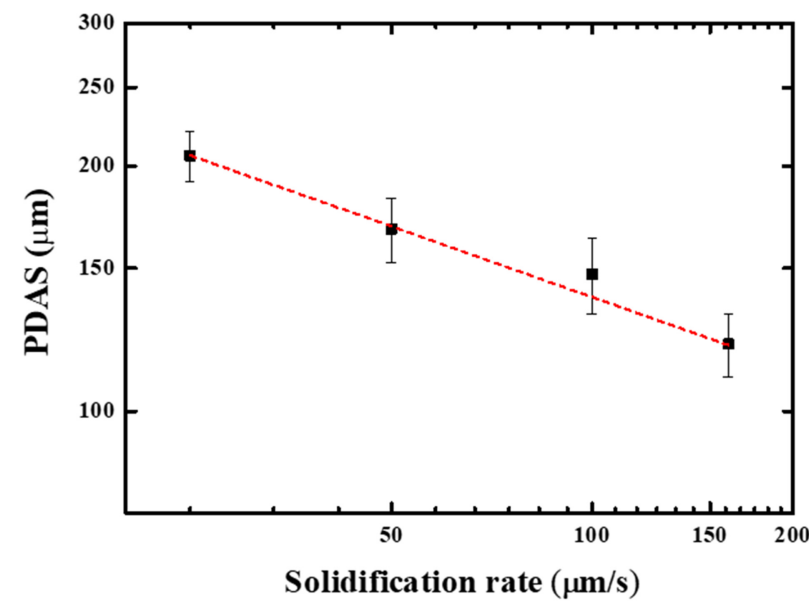

(a)

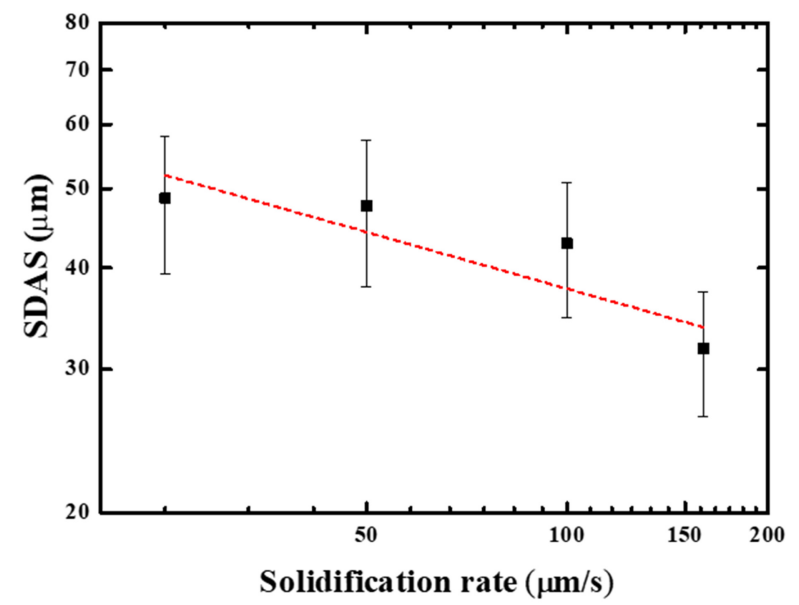

(b)

Fig. 9. Variation of (a) primary dendrite arm spacing and (b) secondary dendrite arm spacing with solidification velocity.

차 수지상 간격과 2 차 수지상 간격은 다음 식으로 나타낼 수 있다.

$$
\begin{aligned}
& \lambda_{P D A S}=K_{1} G^{-1 / 2} V^{1 / 4} \\
& \lambda_{S D A S}=K_{2}(G V)^{-1 / 3}
\end{aligned}
$$

여기서 $k_{1}, k_{2}$ 는 상수이고, 수지상 간격은 온도 경사 $(\mathrm{G})$ 와 응고 속도(V)에 의해 결정된다. 식 (2)와 (3)에 의하면, 1 차 및 2 차 수지상 간격은 온도 경사와 응고 속도가 증가 할수록 감소하게 된다. 본 연구에서는 시드를 이용하여 동 일한 방위의 수지상을 성장시켜 일정한 온도 경사 조건에 서 응고 속도 변화에 따른 수지상 간격 변화를 측정하여 그림 9에 나타내었다. 응고 속도가 증가함에 따라 1차 수 지상 (그림 9(a))과 2차 수지상 (그림 9(b))의 간격은 $\log$ $\log$ 그래프에서 기울기가 각각 -0.288 과 -0.318 로 선형적으 로 감소하는 것이 관찰되었다. 이와 같은 결과는 Hunt 등 [16], Kurz 등[17], Trivedi[18]가 제시한 응고 속도와 수 지상 간격의 상관 관계에 대해 제시한 식 2 및 3 과 거의 유사한 지수 값을 확인할 수 있었다.

\section{3 편석 거동}

수지상 성장 과정에서 합금 원소들의 편석 거동을 살펴 보기 위해 응고 속도를 $100 \mu \mathrm{m} / \mathrm{s}$ 로 일방향 응고하여 고상 /액상 계면으로부터 $20 \mathrm{~mm}$ 직하에서 수직으로 절단하여 후 방산란전자(Back Scattered Electron, BSE)를 이용하여 미 세조직을 관찰하여 그림 10 에 나타내었다. 수지상의 형태 로 고상이 성장할 때 고용 한도 이상의 용질 원소는 액상 으로 배출되는데, 1 차 수지상의 성장 방향으로의 배출은 미미하며 대부분 1 차 수지상 사이로 주로 배출되어 미세 편석이 형성된다. 후방산란전자를 이용한 미세조직 관찰의 경우 첨가 원소의 분포에 따라 명암의 차이가 발생하며, 무거운 원소가 많을수록 상대적으로 밝게 나타나고 가벼운 원소가 많을수록 상대적으로 어둡게 나타난다.

수지상과 수지상 사이 간의 조성 차이뿐만 아니라 수지 상 내부에서도 구간별 조성 차이가 발생하는 것을 그림 10(a)에서 확인할 수 있다. 그림 10(a)에서 1차 수지상 1 영역, 그림 10(b)), 2차 수지상(2 영역, 그림 10(c)) 및 수 지상 사이(3 영역, 그림 10(d))로 구분하였을 때, 1차 수지 상에서 액상으로 결정이 성장할수록 $\gamma^{\prime}$ 상이 조대하게 형 성되는 것을 관찰할 수 있었다. 이 현상은 결정이 성장하
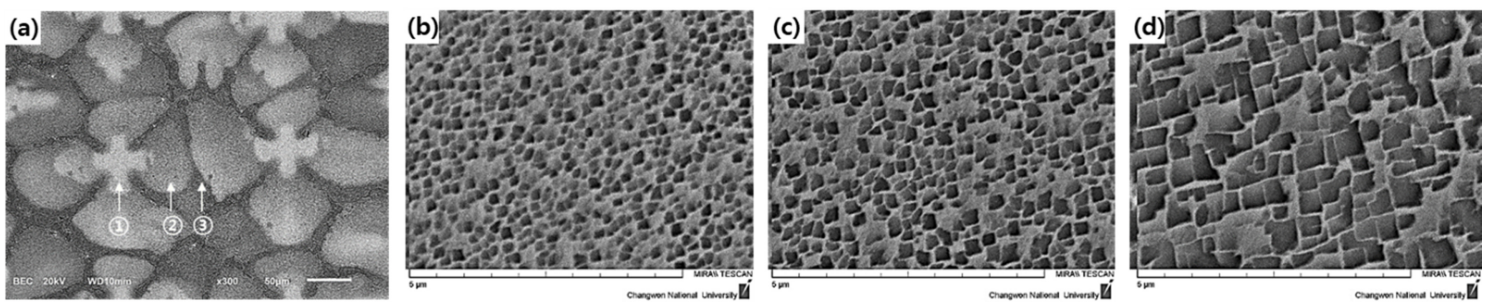

Fig. 10. (a) BSE image showing the change in the brightness at each location of dendrite grown at solidification velocity of $100 \mathrm{~mm} / \mathrm{s}$ and variation of the size of $g^{\prime}$ phase at (b) primary dendrite core, (c) secondary dendrite, and (d) interdendritic region. 
Table 2. Chemical concentration distribution at each location of dendrite.

\begin{tabular}{cccccccccccc}
\hline Composition & Co & $\mathrm{Cr}$ & $\mathrm{Mo}$ & $\mathrm{W}$ & $\mathrm{Al}$ & $\mathrm{Ti}$ & $\mathrm{Ta}$ & $\mathrm{Hf}$ & $\mathrm{Re}$ & $\mathrm{Ni}$ \\
\hline PDA $^{*}$ & 10.27 & 6.16 & 0.60 & 10.44 & 4.63 & 0.52 & 4.36 & - & 4.39 & 58.61 \\
\hline SDA $^{* *}$ & 9.81 & 6.18 & 0.65 & 8.71 & 5.16 & 0.66 & 5.14 & 0.08 & 3.34 & 60.26 \\
\hline $\mathrm{IR}^{* * *}$ & 9.19 & 6.11 & 0.57 & 6.07 & 5.85 & 1.16 & 7.85 & 0.06 & 1.75 & 61.38 \\
\hline
\end{tabular}

-PDA*: Primary dendrite arm $\cdot \mathrm{SDA}^{* *}$ : Secondary dendrite arm $\cdot \mathrm{IR}^{* * *}$ : Interdendritic region
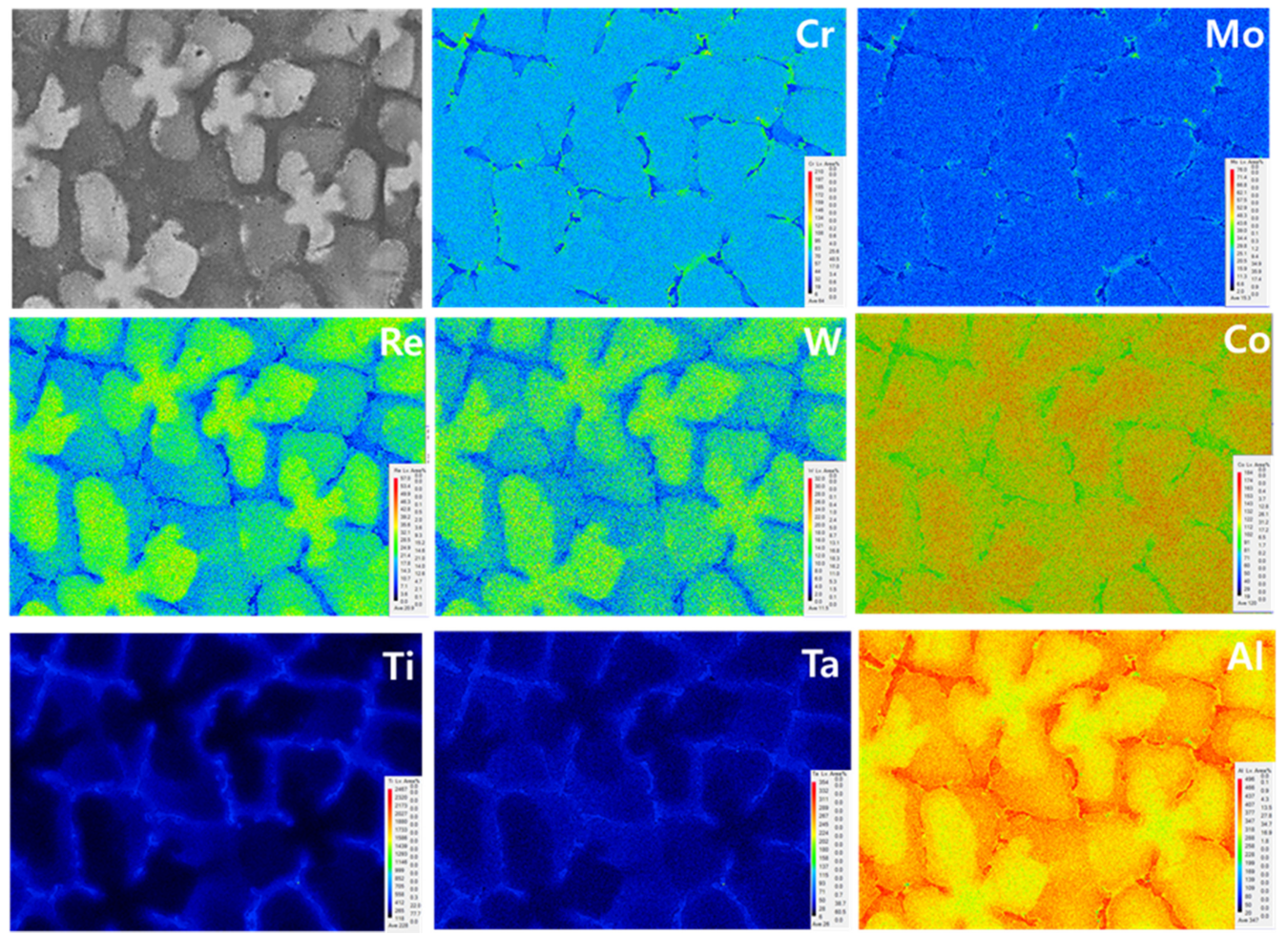

Fig. 11. Distribution of alloy elements after directional solidification at $100 \mu \mathrm{m} / \mathrm{s}$.

면서 용질원소의 재분배에 의해 $\gamma^{\prime}$ 상 형성 및 성장 조장 원소들이 1 차 수지상 보다는 2 차 수지상 및 수지상 사이 에 더 많이 분포되기 때문으로 사료된다. 위치에 따른 조 성의 변화를 관찰하기 위하여 EPMA 분석하여 그 결과를 정량 분석한 결과를 표 2에 나타내었고, 성분 분포 맵핑 결과를 그림 11 에 나타내었다. $\mathrm{Re}, \mathrm{W}$ 및 $\mathrm{Co}$ 와 같이 상 대적으로 무거운 원소들은 1차 수지상에 더 많이 분포하 고 있으며, $\mathrm{Ti}$ 과 $\mathrm{Ta}, \mathrm{Al}$ 은 수지상 사이에 더 많이 분포하 고 있은 것을 확인할 수 있었다. 또한 $\mathrm{Cr}$ 과 $\mathrm{Mo}$ 원소는 편석이 거의 없이 균일하게 분포하고 있음을 관찰할 수 있 었다. 용질 원소가 각 위치에서 다른 분포를 나타내는 이 유는 $\mathrm{Ni}$ 용매원소와 용질원소간 평형분배계수 $(k)$ 의 차이 때 문으로 사료된다. $\mathrm{Re}, \mathrm{W}$ 및 $\mathrm{Co}$ 는 $k$ 값이 1 보다 크고, Ti, $\mathrm{Ta}$, 및 $\mathrm{Al}$ 은 평형분배 계수가 1 보다 작으며, $\mathrm{Cr}$ 과 $\mathrm{Mo}$ 의 $k$ 값이 거의 1 에 근접하기 때문으로 판단된다.

\section{4 열처리에 따른 미세조직 변화}

본 연구에서 사용된 단결정 초내열합금 $\mathrm{CMSX}-4$ 는 고용 강화와 $\gamma^{\prime}$ 상의 석출 강화형 합금으로 잘 알려져 있다 [19,20]. $100 \mu \mathrm{m} / \mathrm{s}$ 의 응고 속도로 성장한 조건에서 위치 변화에 따른 $\gamma^{\prime}$ 상의 불균일한 분포와 합금 원소들의 분포 를 그림 10 과 그림 11 에 나타내었다. 기지 내 편석된 합 금 원소를 균질화 시키고 일정한 $\gamma^{\prime}$ 상의 크기와 분율을 기지 내 전반적으로 석출시키기 위해 표준 열처리를 실시 하였으며 용체화 열처리와 시효 열처리 사이클을 표 3 에 나타내었다.

열처리 전과 후 수지상의 각 위치에서 $\gamma^{\prime}$ 상의 형상 변 화를 관찰하기 위하여 응고 속도를 $50,160 \mu \mathrm{m} / \mathrm{s}$ 로 일방 향 응고한 후 열처리를 실시하여 고상/액상 계면으로부터 $20 \mathrm{~mm}$ 직하에서 수직으로 절단하여 미세조직을 관찰하여 그림 12에 나타내었다. 각각의 응고 속도에서 열처리를 실 
Table 3. Heat treatment cycles of CMSX-4 alloy.

\begin{tabular}{|c|c|}
\hline \multicolumn{2}{|c|}{ Heat Treatment } \\
\hline & $1,277^{\circ} \mathrm{C} \times 4 \mathrm{~h} \rightarrow 1,287^{\circ} \mathrm{C} \times 2 \mathrm{~h} \rightarrow 1,296^{\circ} \mathrm{C} \times 3 \mathrm{~h}$ \\
\hline Solution & $\begin{aligned} \rightarrow 1,304^{\circ} \mathrm{C} \times 3 \mathrm{~h} & \rightarrow 1,313^{\circ} \mathrm{C} \times 2 \mathrm{~h} \rightarrow 1,316^{\circ} \mathrm{C} \\
\times 2 \mathrm{~h} & \rightarrow 1,318^{\circ} \mathrm{C} \times 2 \mathrm{~h}\end{aligned}$ \\
\hline 1st Aging & $1,140^{\circ} \mathrm{C} \times 6 \mathrm{~h}$ \\
\hline 2nd Aging & $871^{\circ} \mathrm{C} \times 20 \mathrm{~h}$ \\
\hline
\end{tabular}

시하기 전 수지상 구조를 명확하게 보여주고 있는 반면에 열처리를 실시한 이후 균질화가 되어 1차 수지상, 2차 수 지상 및 수지상 사이 지역에서 명암 차이가 감소한 것이 관찰되었다. 열처리 전 $\gamma^{\prime}$ 상의 거동을 관찰한 결과, 응고 속도에 관계 없이 수지상 중심에는 미세하면서 균일한 $0.6 \mu \mathrm{m}$ 크기의 $\gamma^{\prime}$ 상이 석출되었지만 수지상 사이에서는 비 교적 조대한 $\gamma^{\prime}$ 상이 석출되는 것이 관찰되었다. 특히 두 응고 속도에서 성장한 조직에서 수지상의 중심부와 비교하 면 수지상 사이에 조대한 $\gamma^{\prime}$ 상이 관찰되었다. $50 \mu \mathrm{m} / \mathrm{s}$ 의
속도로 느리게 응고되었을 때 $160 \mu \mathrm{m} / \mathrm{s}$ 의 속도로 빠르게 응고된 조직과 비교하면 균일하지만 조대한 $\gamma^{\prime}$ 상이 석출 되는 것을 확인할 수 있었다. 열처리 후 $\gamma^{\prime}$ 상의 거동을 관찰한 결과 수지상 중심부에는 응고 속도에 관계없이 미 세하면서 균일한 $\gamma^{\prime}$ 상이 석출하였는데, 수지상 사이에는 불균일하고 조대한 $\gamma^{\prime}$ 상이 석출되었고, $\gamma$ 상의 두께도 수지 상 중심부와 비교하면 두껍게 형성되었다. $160 \mu \mathrm{m} / \mathrm{s}$ 의 응 고 속도로 성장한 시편과 비교하면 $50 \mu \mathrm{m} / \mathrm{s}$ 의 응고 속도 로 성장한 시편에서 더 조대한 $\gamma^{\prime}$ 상이 석출되었고 $\gamma$ 상의 두께도 더 두껍게 형성되었다.

열처리 이후 위치에 따른 조성 변화를 살펴보기 위해 EPMA 분석하여 그 결과를 그림 13에 나타내었다. 수지상 중심에 편석되는 원소들 $(\mathrm{Re}, \mathrm{W}$, 그리고 $\mathrm{Co})$ 이 원자번호 가 높은 원소들이기 때문에 확산 속도가 느리므로[21] 열 처리 이후에도 약간의 편석이 존재하는 것으로 확인 되었 다. 그림 13 에서 열처리 이후 $50 \mu \mathrm{m} / \mathrm{s}$ 의 응고 속도에서 편석 정도가 비교적으로 더 높은 것이 관찰되었다. 그 이

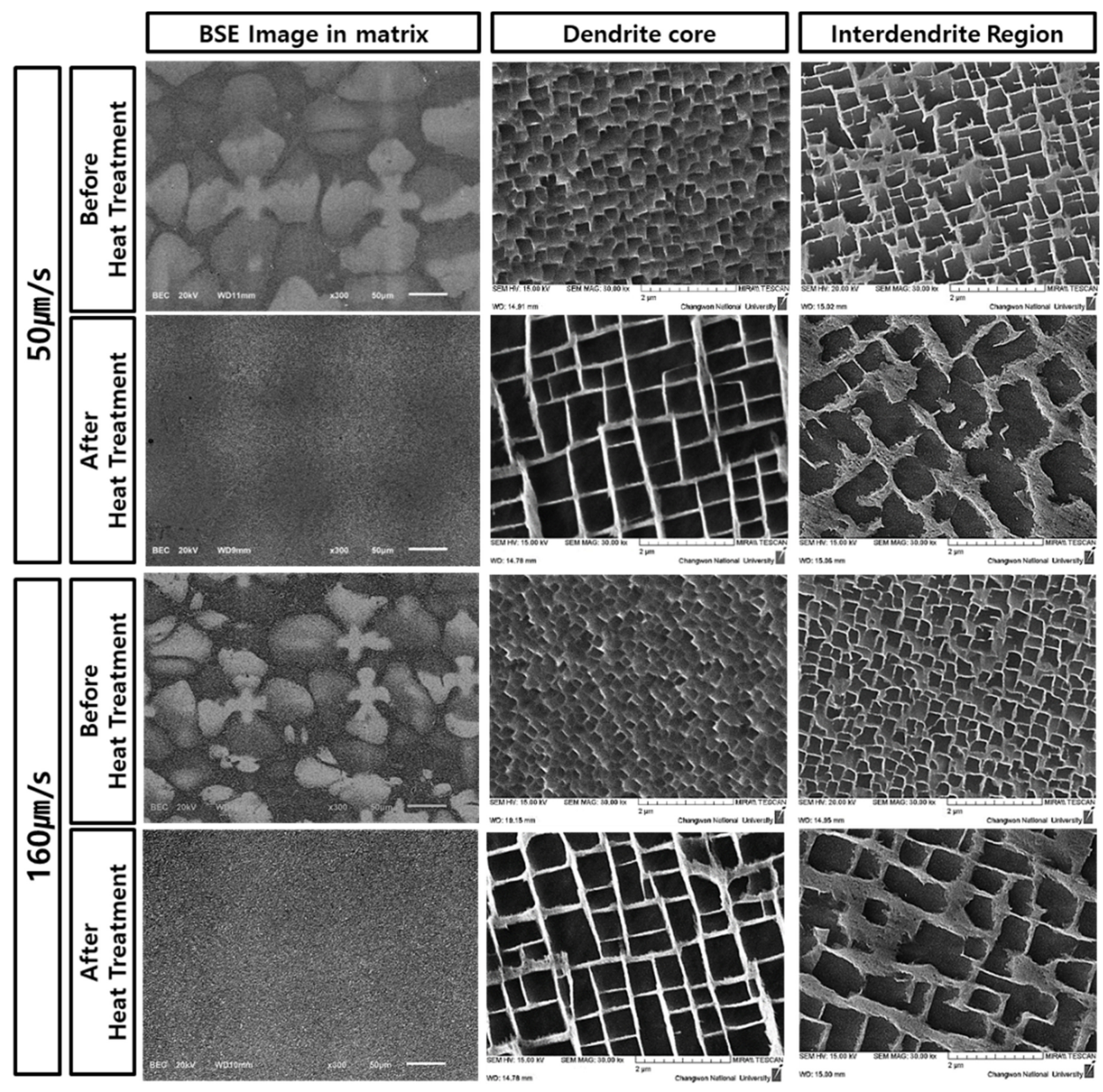

Fig. 12. Variation of $\mathrm{g}^{\prime}$ phase morphology before and after heat treatment at different growth velocity. 


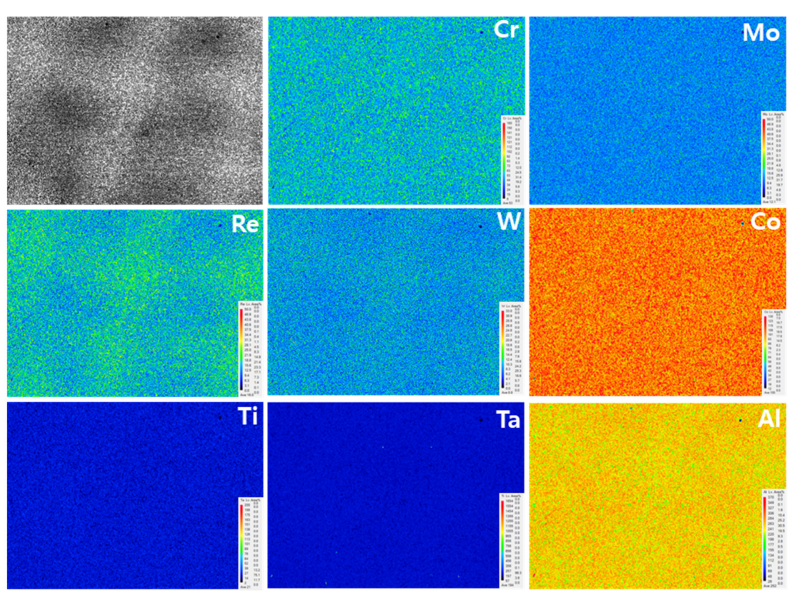

(a)

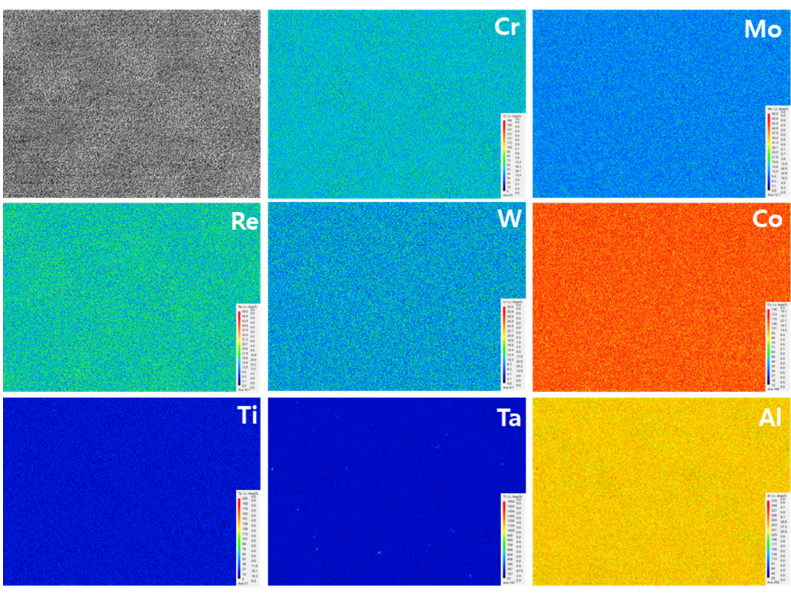

(b)

Fig. 13. EPMA map showing an alloy elements distribution after heat treatment in the specimen grown at (a) 50 and (b) $160 \mu \mathrm{m} / \mathrm{s}$.

유는 응고 속도가 느릴수록 수지상 팁(Tip)의 온도는 더 높은 온도에서 성장하게 되므로 평형분배계수가 1 보다 큰 원소의 경우 편석의 정도가 더 높게 되고, 동일한 열처리 를 진행하더라도 수지상 간격이 넓을수록 수지상 중심-수 지상 사이 간의 거리가 증가하기 때문에 합금 원소들이 균 질화를 위한 확산 거리가 증가하여 농도의 불균일성이 약 간 존재하는 것으로 사료된다. 결과적으로 $50,160 \mu \mathrm{m} / \mathrm{s}$ 의 응고 속도에서 열처리 이후 고용 강화형 원소 $(\mathrm{Re}, \mathrm{W}, \mathrm{Co})$ 가 수지상 중심에 편석되고, $\gamma^{\prime}$ 상의 형성원소 $(\mathrm{Al}, \mathrm{Ti}, \mathrm{Ta})$ 가 수지상 사이에 편석되어 그림 12 에 나타낸 불균일한 형상의 $\gamma^{\prime}$ 이 석출되고 편석 정도는 $50 \mu \mathrm{m} / \mathrm{s}$ 에서 더 강하 게 존재하기 때문에 불균일한 형상의 $\gamma^{\prime}$ 의 수가 많은 것 으로 사료된다. 위의 결과로부터 응고 속도가 느려서 수지 상 간격이 넓은 경우, 용체화 열처리 시간을 길게하여 용 질원소들의 확산에 의해 응고 중에 형성된 성분들의 편석
정도를 감소시킬 수 있다. 하지만, 이 방법은 효율성이 떨 어지므로 응고 중에 미세조직 및 편석 정도를 제어하여 용 체화 열처리 시간을 감소시킬 수 있을 것으로 판단된다.

\section{4. 결 론}

본 연구에서 단결정 시드를 이용하여 단결정 초내열합금 $\mathrm{CMSX}-4$ 의 성장 거동을 관찰하였고, 응고 속도 및 열처리 에 따른 수지상 형상 변화, 편석 거동을 분석하여 다음과 같은 결론을 얻었다.

1. 시드를 이용한 일방향 응고 시 용융 금속으로부터 성 장하는 수지상의 방위는 시드의 수지상 방위와 동일하게 성장하였으며 $\mathrm{EBSD}$ 분석을 통하여 단결정 성장을 확인하 였다.

2. 일방향 응고 시 $25-160 \mu \mathrm{m} / \mathrm{s}$ 의 응고 속도 범위 내에 서 CMSX-4 초내열합금은 수지상으로 성장하였으며 응고 속도가 증가할수록 수지상은 미세해지며, 1차 수지상 간격 과 2 차 수지상 간격은 응고속도 $(\mathrm{V})$ 와 각각 $\mathrm{V}^{-0.288}$ 와 $\mathrm{V}^{-0.318}$ 의 직선적인 관계임을 확인하였다.

3. 합금이 수지상으로 성장할 때, 합금 원소에 따른 평형 분배계수 차이 때문에 원소 별로 편석되는 위치가 다르게 된다. $\mathrm{Re}, \mathrm{W}, \mathrm{Co}$ 는 수지상 중심에 편석되며 $(\mathrm{k}>1), \mathrm{Al}$, $\mathrm{Ti}, \mathrm{Ta}$ 은 수지상 사이에 편석된다 $(\mathrm{k}<1)$.

4. 응고 이후 균질화 열처리를 실시하더라도 수지상 사 이에 비교적 조대한 $\gamma^{\prime}$ 상이 형성되었다. $50 \mu \mathrm{m} / \mathrm{s}$ 의 응고 속도로 성장한 시편에서 수지상 간격이 증가하게 되어 열 처리 이후 $\mathrm{Al}, \mathrm{Ti}, \mathrm{Ta}$ 원소의 편석 정도가 더 높기 때문 에 조대한 $\gamma^{\prime}$ 상이 형성되었다.

\section{ACKNOWLEDGEMENT}

이 논문은 2018년도 정부(교육과학기술부)의 재원으로 한국연 구재단의 지원을 받아 수행된 연구이며(No.2018R1A5A6075959), 산업통상자원부지원 에너지기술평가원의 에너지기술개발사업 (2016 11 20100370) 및 에너지 인력사업(20174030201460) 의 연구비 지원에 의하여 연구되었다.

\section{REFERENCES}

1. R. C. Reed, The superalloys: Fundamentals and Applications, pp.18-25, Cambridge University Press, Cambridge, UK (2008).

2. B. G. Choi, I. S. Kim, H. U. Hong, J. H. Do, J. E. Jung, and C. Y. Jo, Met. Mater. Int. 23, 877 (2017). 
3. T. M. Pollock and S. Tin, J. Propul. Power 22, 361 (2006).

4. C. T. Sims, N. S. Stoloff, and W. C. Hager, Superalloy II, pp.97-131, Wiley-Interscience publication, New York, USA (1987).

5. R. C. Reed, The superalloys: Fundamentals and Applications, pp.33-54, Cambridge University Press, Cambridge, UK (2008).

6. B. C. Wilson, J. A. Hickman, and G. E. Fuchs, J. Min. Met. Mater. Soc. 55, 35 (2003).

7. D. A. Porter and K. E. Easterling, Phase Transformations in Metals an Alloys, pp.233-239, Van Nostrand Reinhold Co. Ltd., New York, USA (1981).

8. J. R. Davis, ASM Handbook: Casting, pp.338-345, ASM International, OH, USA (2008)

9. S. F. Gao, L. Liu, N. Wang, W. B. Zhao, J. Zhang, and H. Z. Fu, Metall. and Mater. Trans. A 43, 3767 (2012).

10. N. D’souza, M. G. Ardakani, A. Wagner, B. A. Shollock, and M. Mclean, J. Mat sci. 37, 481 (2002).

11. N. Stanford, A. Djakovic, B. A. Shollock, M. Mclean, N. D'souza, and P. A. Jennings, Scripta Mater. 50, 159 (2004)

12. P. Hallensleben, H. Schaar, P. Thome, N. Jöns, A.
Jafarizadeh, I. Steinbach, G. Eggeler, and J. Frenzel, Mater. Des. 128, 98 (2017).

13. J. S. Lee, J. H. Gu, H. M. Jung, E. H. Kim, Y. G. Jung, and J. H. Lee, Mater. Today Proc. 1, 3 (2014).

14. J. H. Gu, C. H. Sung, J. H. Shin, S. M. Seo, and J. H. Lee, Korean J. Met. Mater. 54, 261 (2016).

15. X. B. Meng, Q. Lu, X. L. Zhang, J. G. Li, Z. Q. Chen, Y. H. Wang, Y. Z. Zhou, T. Jin, X. F. Sun, and Z. Q. Hu, Acta Mater. 60, 3965 (2012).

16. J. D. Hunt and S. Z. Lu, Metall. Mater. Trans. A 27, 611 (1996).

17. W. Kurz and D. J. Fisher, Acta Metall. 29, 11 (1981).

18. R. Trivedi, Metall. Trans. A 15, 977 (1984).

19. R. C. Reed, The superalloys: Fundamentals and Applications, pp.90-102, Cambridge University Press, Cambridge, UK (2008).

20. C. T. Sims, N. S. Stoloff, W. C. Hager, Superalloy II, pp.101-110, Wiley-Interscience publication, New York, USA (1987).

21. B. S. Bokstein, A. I. Epishin, T. Link, V. A. Esin, A. O. Rodin, and I. L. Svetlov, Scripta Mater. 57, 801 (2007). 